\title{
VIRULENCE OF PUCCINIA RECONDITA F. SP. TRITICI ON WINTER WHEAT IN UKRAINE IN 2007
}

\author{
Sarhang Elyasi-Gomari ${ }^{*}$, Lesovaya Galina Mikhailovno ${ }^{2}$ \\ ${ }^{1}$ Azad Islamic University, Shoushtar Branch, Shoushtarno Area, Department of Agriculture, 6451741117, Iran \\ ${ }^{2}$ Institute of Plant Protection, 33 Vasilkovskaya Str. 03022, Kiev-22, Ukraine
}

Received: December 12, 2008

Accepted: October 27, 2009

\begin{abstract}
Thatcher and 36 near-isogenic Thatcher lines with different Lr genes for resistance to Puccinia recondita f. sp. tritici were planted in field plots at one location each in the eastern and central parts of the forest-steppe region of Ukraine where they were exposed to natural epiphytotics of leaf rust. Disease severity on the lines indicated that Lr9, Lr19, Lr24, Lr25, and Lr28 had highly effective resistance in both locations. Lines with Lr27+Lr31, Lr35, and Lr36 were resistant in the eastern location and highly resistant in central location. Bulk collections of $P$. recondita from fields of nine Ukrainian winter wheat cultivars in the eastern location were inoculated onto seedlings of each of the 36 Thatcher near-isogenic lines. Lines with Lr9, Lr19, Lr24, Lr25, and Lr28 remained free or nearly free of uredinia. A total of 133 single-uredinial isolates obtained from 19 susceptible Thatcher near-isogenic lines in field plots in the central part of the forest-steppe region were identified to race using the eight standard leaf rust differential varieties of Johnson and Browder. The most common races were races $6(27.8 \%), 77(18.0 \%), 149(13.5 \%)$, and X-4 $(9.8 \%)$. The three most common races were not found on the Lr26 line and may lack virulence to it.
\end{abstract}

Key words: Puccinia triticina, winter wheat, race-specific resistance

\section{INTRODUCTION}

Wheat leaf rust, caused by the fungus Puccinia recondita Rob. ex Desm. f. sp. tritici Erikss. [= P. triticina (Anikster et al. 1997)] is a common pathogen of wheat (Triticum aestivum L.) and causes significant yield losses in many wheat-growing areas throughout the world. Fungicide applications are costly and not always advisable ecologically. Consequently, use of leaf rust resistant wheat varieties is widely recommended to reduce yield losses (Anikster et al. 1997; Bartos et al. 2001a). Research on genetics of resistance in wheat and virulence of the pathogen are needed for using most efficiently available race-specific resistance genes and to avoid epiphytotics caused by new highly virulent races of the leaf rust pathogen. Such research is especially important when there is evidence that the resistance genes in wheat varieties that are widely grown over large areas in one or many geographical regions have begun to lose their effectiveness. Selection of new leaf rust resistance in wheat will be more intensive and purposeful if wheat breeders are provided with the information on useful resistance donor lines, effectiveness of their resistance genes in a particular region, and diversity and virulence of local leaf rust population (Alekseeva et al. 1990; Bartos et al. 2001b; Kolmer 2002; Kolmer 1997; Long et al. 2002; Singh 1991). Regular surveys of virulence of $P$. recondita $\mathrm{f}$. sp. tritici in major regions of wheat cultivation are of fundamental importance for forecasting pathogen virulence changes in efforts to preserve effectiveness of resistance genes and limit disease losses. Hence, we have analyzed the frequencies of races and virulence of $P$. recondita $\mathrm{f}$. sp. tritici populations in Ukraine. The objectives of this study were to characterize the virulence of $P$. recondita populations in the central and eastern part of Ukrainian forest-steppe in 2007 and to compare these results with those of previous surveys.

\section{MATERIALS AND METHODS}

Effectiveness of leaf rust resistance genes in Ukraine

In field tests, the near-isogenic lines of Thatcher with single genes for leaf rust resistance were planted in test plots at two locations. The first location was in eastern part of the forest-steppe area of Ukraine (Kharkiv region), and the second was in the central part of the foreststeppe area (Kiev region). Plots consisted of $1 \mathrm{~m}$ rows of Thatcher plus 36 near-isogenic lines in blocks surrounded with spacing rows of a susceptible wheat variety. At the Kiev location Thatcher was not included in the test with the 36 near-isogenic lines. The 36 Thatcher near-isogenic lines included lines with Lr1, Lr2a, Lr2b, Lr2c, Lr3, Lr3ka, Lr3bg, Lr9, Lr10, Lr11, Lr12, Lr13, Lr14a, Lr14b, Lr15, Lr16, Lr17, Lr18, Lr19, Lr20, Lr21, Lr22a, Lr23, Lr24, Lr25, Lr26, Lr27+31, Lr28, Lr29, Lr30, Lr32, Lr33, Lr34, Lr35, Lr36, and Lr37. Natural epiphytotics of leaf rust developed in the plots at both locations in 2007, and the leaf rust reaction type and severity on each line were evalu- 
ated at several equidistant places within each plot during the time of maximum rust development (milk-dough stage). Leaf rust severity was estimated visually using the integrated scale for rust evaluation as a measure of the effectiveness of individual leaf rust resistance genes against a naturally occurring population of $P$. recondita $\mathrm{f}$. sp. tritici at each test location. The integrated rust scale was developed by a group of cereal rust scientists in Ukraine for assessing resistance to leaf rusts in wheat, rye, barley, and oat (Goel and Saini 2001). A comparison between the integrated scale and the international unified leaf rust scale (Johnston and Browder 1964) is shown in table 1.

Table 1. Comparison of integrated scale and international unified scale for level of resistance in wheat to P. recondita f. sp. tritici

\begin{tabular}{|l|c|c|}
\hline \multicolumn{1}{|c|}{ Description of reactions } & $\begin{array}{c}\text { Integrated } \\
\text { scale }\end{array}$ & $\begin{array}{c}\text { International } \\
\text { unified scale }\end{array}$ \\
\hline $\begin{array}{l}\text { Very highly resistant no uredinia } \\
\text { or other macroscopic signs of } \\
\text { infection }\end{array}$ & 9 & VR \\
\hline $\begin{array}{l}\text { Highly resistant no uredinia, } \\
\text { but hypersensitive necrotic or } \\
\text { chlorotic flecks of varying size }\end{array}$ & 8 & R \\
\hline $\begin{array}{l}\text { Resistant small or intermediate } \\
\text { sized uredinia surrounded } \\
\text { by necrosis or chlorosis, with } \\
\text { uredinia occupying up to } 10 \% \text { of } \\
\text { leaf area }\end{array}$ & 7 & R \\
\hline $\begin{array}{l}\text { Resistant small or intermediate } \\
\text { size uredinia surrounded by } \\
\text { necrosis or chlorosis, with } \\
\text { uredinia occupying up to } 15 \% \text { of } \\
\text { leaf area }\end{array}$ & 6 & MR \\
\hline $\begin{array}{l}\text { Moderately susceptible } \\
\text { intermediate size uredinia with } \\
\text { little necrosis or chlorosis, and } \\
\text { with uredinia occupying up to } \\
\text { 25\% of leaf area }\end{array}$ & 5 & LM, \\
\hline $\begin{array}{l}\text { Susceptible intermediate to } \\
\text { large uredinia, with uredinia } \\
\text { occupying up to } 40 \% \text { of leaf area }\end{array}$ & 4 & M, \\
\hline $\begin{array}{l}\text { Susceptible intermediate to } \\
\text { large uredinia, with uredinia } \\
\text { occupying up to } 90 \% \text { of leaf area }\end{array}$ & 3 & SM \\
\hline $\begin{array}{l}\text { Highly susceptible large } \\
\text { uredinia occupying up to 90\% of } \\
\text { leaf area }\end{array}$ & 2 & SHS \\
\hline $\begin{array}{l}\text { Very highly susceptible large } \\
\text { uredinia occupying up to } 100 \% \\
\text { of leaf area }\end{array}$ & 1 & \\
\hline
\end{tabular}

"H - high; L - light; $\mathrm{M}$ - moderate; $\mathrm{R}$ - resistant; $\mathrm{S}$ - susceptible; $\mathrm{V}$ - very

\section{Virulence of $P$. recondita f. sp. tritici from Ukranian wheat cultivars}

Leaves infected with $P$. recondita were collected from nine regional and perspective Ukrainian winter wheat cultivars, Kryzhynka, Smuglyanka, Prichernomorka, Astet, Perlina Lisostepu, Dolgushinskaya, Kharkovskaya 105, Donetskaya 48 and Ukrainka Odeskaya in the eastern part of the forest-steppe region of Ukraine in 2007. Rusted leaves were collected at 10 equidistant sites within plots of each of the nine cultivars according to standard procedures (Shopina 1967) during the time of maximum rust development (milk-dough stage). In the laboratory, a piece of each rusted leaf sample was placed in a flask with water plus a detergent Tween-80 ( 1 or 2 drops per $1)$, and the flask was shaken to produce a suspension of urediniospores. The urediniospore suspension from each leaf was used to inoculate a set of seedlings of the 36 nearisogenic Thatcher lines. The seedlings were grown in soil in boxes in the greenhouse and inoculated at 10 days after planting when their second leaves were beginning to form. After being sprayed with urediniospore suspensions, the seedlings were incubated for one day at 100\% $\mathrm{RH}$ before being returned to the greenhouse. 15 days after inoculation, rust severity on each of the 36 near-isogenic lines was estimated as the percentage of leaf area affected based on Strakhov's scale (Starakhov 1951), which was adapted from the scale of Peterson (Peterson et al. 1948) with gradations of $0,5,15,45,65$, and $100 \%$ infection relative to the area of the leaf covered by pustules at the maximum level of leaf rust infection.

\section{Virulence of $P$. recondita $f$. sp. tritici collected from near-isogenic lines of Thatcher wheat}

Leaves infected with leaf rust were collected from Thatcher wheat and the 36 near-isogenic Thatcher lines in field plots in the central part of the forest-steppe region of Ukraine in 2007 at the time of maximum rust development (milk-dough stage). Each rusted leaf was placed in a filter paper package and the package was labeled. Packages of rusted leaves were held at $4^{\circ} \mathrm{C}$ in a refrigerator until urediniospores were collected for inoculation in the greenhouse. Urediniospores were collected by placing a piece of the rusted leaf sample in a flask with water plus a detergent Tween-80, and the flask was shaken to produce a suspension of urediniospores. The urediniospore suspension was sprayed onto detached leaf pieces of the susceptible wheat variety Eritrospermum 15 in a Petri dish on water agar plus benzimidazole at $0.004 \mu \mathrm{g} / \mathrm{ml}$ to obtain isolates from single uredinia (Mikhailova and Kvitko 1970). The Petri dishes were covered with moistened filter paper to maintain $100 \%$ RH for 1 day. After 1 day, the filter paper was removed and the closed Petri dishes were incubated at $24^{\circ} \mathrm{C}$ under artificial light at $10^{5}$ lux. When chlorotic spots indicating leaf rust infection became visible, leaf pieces bearing single leaf rust infections were transferred to fresh Petri dishes. At 10 days after inoculation, when uredinia with abundant sporulation were present on the single uredinium leaf pieces, urediniospores of the single uredinial isolates were transferred with a soft brush and spread over detached leaves of Eritrospermum 15 wheat on water agar with benzimidazole in a Petri dish to increase the urediniospores of the isolate prior to inoculation of the differential varieties for race identification. Two single uredinial isolates were established from each individual rusted leaf that was collected from the field. The single uredinial isolates were tested for virulence on the eight standard differential varieties (Johnston and Browder 1964; Kolmer 2002). Detached leaves of each differential variety were incubated under artificial light on water agar with benzimidazole as described for establishment of single uredinial isolates. Leaves of each differential variety were placed in a separate Petri dishes. The detached leaves were inoculated by spraying with a sus- 
pension of urediniospores of a single uredinial isolate in water with Tween 80 and incubated one day in Petri dishes covered with moist filter paper as described above. After one day the most filter paper was removed from the Petri dishes and replaced with glass covers. After 10 days under artificial light at $24^{\circ} \mathrm{C}$, the leaf rust reaction types on each differential variety were determined according to Mains and Jackson's scale (Mains and Jackson 1926).

\section{RESULTS}

Determination of wheat resistance genes effectiveness

During the natural epiphytotics of leaf rust in the eastern and central part of Ukrainian forest-steppe the most efficient resistance genes in the field plots of the near-iso- genic Thatcher lines in both regions were Lr9, Lr19, Lr24, Lr25, Lr27+31, Lr28, Lr35 and Lr36 (Table 2). Resistance genes Lr3bg, Lr12, Lr13, Lr18, Lr21, Lr22a, Lr23, Lr26, Lr29, Lr30, Lr32, and Lr33 also provided effective resistance in the central part of the Ukrainian forest-steppe region, although the level of resistance provided by Lr3bg, Lr12, Lr13, Lr26, Lr30, Lr32, and Lr33 was somewhat lower that provided by Lr18, Lr21, Lr22a, and Lr29. The epiphytotic in the central part of the forest-steppe region was less severe than the epiphytotic in the eastern part as indicated by the resistance rating of 3 for Thatcher and the Lr37 line in the central part compared to the lower rating of 1 for 23 of the near-isogenic lines in the eastern part of the forest-steppe region (Table 2).

Table 2. The results of assessment of resistance level of Thatcher near-isogenic lines against the local population of P. recondita f. sp. tritici in the forest-steppe region of Ukraine in 2007

\begin{tabular}{|c|c|c|c|c|c|c|c|c|c|}
\hline \multirow{3}{*}{$\begin{array}{l}\text { Line } \\
\text { Lr1 }\end{array}$} & \multicolumn{4}{|c|}{ Resistance rating } & \multirow{3}{*}{$\begin{array}{l}\text { Line } \\
\text { Lr20 }\end{array}$} & \multicolumn{4}{|c|}{ Resistance rating } \\
\hline & \multicolumn{2}{|c|}{$\begin{array}{c}\text { eastern part } \\
\text { of forest-steppe }\end{array}$} & \multicolumn{2}{|c|}{$\begin{array}{c}\text { central part } \\
\text { of forest-steppe }\end{array}$} & & \multicolumn{2}{|c|}{$\begin{array}{c}\text { eastern part } \\
\text { of forest-steppe }\end{array}$} & \multicolumn{2}{|c|}{$\begin{array}{c}\text { central part } \\
\text { of forest-steppe }\end{array}$} \\
\hline & $1^{+}$ & $\mathrm{S}^{\ddagger}$ & $4^{+}$ & $\mathrm{MS}^{\ddagger}$ & & $1^{+}$ & $\mathrm{VS}^{\ddagger}$ & $5^{+}$ & $\mathrm{M}^{\ddagger}$ \\
\hline Lr2a & 1 & VS & $4-5$ & MS-M & Lr21 & 4 & MS & $8-7^{*}$ & $\mathrm{R}$ \\
\hline Lr2b & 1 & VS & 5 & $\mathrm{M}$ & Lr22a & 1 & VS & $8^{*}$ & $\mathrm{R}$ \\
\hline Lr2c & 1 & VS & 4 & MS & Lr23 & 1 & VS & $9^{*}$ & VR \\
\hline Lr3 & 1 & VS & 4 & MS & Lr24 & $9^{*}$ & VR & $9^{*}$ & VR \\
\hline Lr3ka & 1 & VS & 4 & MS & Lr25 & $9^{*}$ & VR & $9^{*}$ & VR \\
\hline Lr3bg & 1 & VS & $6^{*}$ & MR & Lr26 & 5 & $\mathrm{M}$ & $6-7^{*}$ & MR-R \\
\hline Lr9 & $9^{*}$ & VR & $9^{*}$ & VR & Lr27+31 & $7^{*}$ & $\mathrm{R}$ & $8^{*}$ & $\mathrm{R}$ \\
\hline Lr10 & 1 & VS & 4 & MS & Lr28 & $9^{*}$ & VR & $9^{*}$ & VR \\
\hline Lr11 & 1 & VS & 5 & $\mathrm{M}$ & Lr29 & 5 & $\mathrm{M}$ & $8-9 *$ & R-VR \\
\hline Lr12 & 1 & VS & $7-6^{*}$ & R-MR & Lr30 & 1 & VS & $6^{*}$ & MR \\
\hline Lr13 & 1 & VS & $6-7^{*}$ & MR-R & Lr32 & 3 & $S$ & $6-7^{*}$ & MR-R \\
\hline Lr14a & 1 & VS & 5 & $\mathrm{M}$ & Lr33 & 1 & VS & $6^{*}$ & MR \\
\hline Lr14b & 1 & VS & 5 & $\mathrm{M}$ & Lr34 & 1 & VS & 3 & S \\
\hline Lr15 & 1 & VS & 5 & $\mathrm{M}$ & Lr35 & $7^{*}$ & $\mathrm{R}$ & $8-9 *$ & R-VR \\
\hline Lr16 & 1 & VS & $5-4$ & M-MS & Lr36 & $7^{*}$ & $\mathrm{R}$ & $8^{*}$ & $\mathrm{R}$ \\
\hline Lr17 & 1 & VS & 5 & $M$ & Lr37 & 1 & VS & 3 & $S$ \\
\hline Lr18 & 4 & MS & $8^{*}$ & $\mathrm{R}$ & Thatcher & - & - & 3 & $\mathrm{~S}$ \\
\hline Lr19 & $9^{*}$ & VR & $9^{*}$ & VR & - & - & - & - & - \\
\hline
\end{tabular}

* types of resistance are: 9 - very resistant (VR); 8, 7 - resistant (R) and 6- moderately resistant (MR)

t by the integrated scale (Goel and Saini 2001)

$\ddagger$ by international scales (Goel and Saini 2001; Johnston and Browder 1964)

\section{Virulence of $P$. recondita $f$. sp. tritici from Ukranian wheat cultivars}

Collections of $P$. recondita urediniospores from leaves of regional and perspective cultivars of winter wheat in the eastern part of Ukrainian forest-steppe in 2007 produced high levels of infection on seedlings of most of the near-isogenic Thatcher lines (Table 3), but little or no infection developed on lines with Lr9, Lr19, Lr24, Lr25, and Lr28. Seedlings of lines with Lr1, Lr2a, Lr2b, Lr2c, Lr26 and Lr27+Lr31 developed somewhat less infection on average than the most susceptible lines (Table 3). In 19881989 all leaf rust isolates tested in Ukraine were virulent to Lr26 (Long et al. 2002), but by 1994, 48\% and by 2003, 40. $2 \%$ of the isolates ere virulent to Lr26 (Elyasi-Gomari and Panteleev 2006).
Although the differences in levels of virulence expressed by collection from the nine different source cultivars were not dramatic, the mean severity over all near-isogenic lines did differ between source cultivars. Urediniospores from the cultivars Kryzhynka and Smuglyanka, which had been rated highly resistant in pervious field evaluation, were more virulent on average than urediniospores from other cultivars, particularly those from the highly susceptible Kharkovskaya 105, Donetskaya 48, and Ukrainka Odeskaya (Table 3). This was true for the lines with most effective resistance (Lr9, Lr19, Lr24, Lr25, and Lr28) and the lines with moderately effective resistance (Lr1, Lr2a, Lr2b, Lr2c, Lr26 and Lr27 + Lr31) as well as for the most susceptible near-isogenic lines. 
Table 3. Leaf rust severity on seedlings of near-isogenic Thatcher lines inoculated with urediniospores of P. recondita collected from nine winter wheat cultivars* in the eastern part of forest-steppe of Ukraine in 2007

\begin{tabular}{|c|c|c|c|c|c|c|c|c|c|c|}
\hline \multirow[b]{2}{*}{ Line } & \multicolumn{9}{|c|}{$\begin{array}{l}\text { Leaf rust severity induced on seedlings of near-isogeinc Thatcher wheat lines by urediniospore } \\
\text { collections from indicated winter wheat cultivars }\end{array}$} & \multirow{2}{*}{ 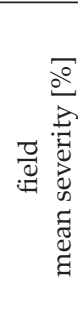 } \\
\hline & 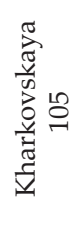 & 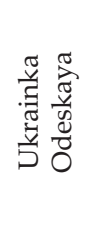 & 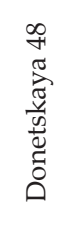 & 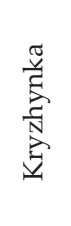 & 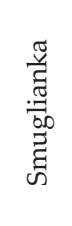 & 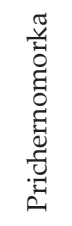 & 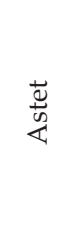 & 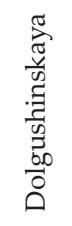 & 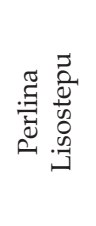 & \\
\hline Lr1 & 62 & 70 & 69 & 80 & 85 & 72 & 75 & 72 & 76 & 73.4 \\
\hline Lr2a & 70 & 74 & 72 & 79 & 77 & 75 & 71 & 78 & 75 & 74.6 \\
\hline Lr2b & 75 & 78 & 80 & 84 & 89 & 80 & 81 & 81 & 80 & 80.9 \\
\hline Lr2c & 78 & 80 & 79 & 90 & 92 & 88 & 87 & 83 & 82 & 84.3 \\
\hline Lr3 & 100 & 100 & 100 & 100 & 100 & 100 & 100 & 100 & 100 & 100.0 \\
\hline Lr3ka & 100 & 100 & 100 & 100 & 100 & 100 & 100 & 100 & 100 & 100.0 \\
\hline Lr3bg & 100 & 100 & 100 & 100 & 100 & 100 & 100 & 100 & 100 & 100.0 \\
\hline Lr9 & 0 & 0 & 0 & 2 & 4 & 1 & 0 & 0 & 0 & 0.8 \\
\hline Lr10 & 90 & 92 & 89 & 90 & 92 & 87 & 85 & 83 & 85 & 88.1 \\
\hline Lr11 & 78 & 81 & 85 & 100 & 100 & 100 & 91 & 89 & 92 & 90.7 \\
\hline Lr12 & 80 & 82 & 78 & 100 & 100 & 100 & 90 & 95 & 97 & 91.3 \\
\hline Lr14a & 90 & 87 & 89 & 90 & 93 & 85 & 84 & 86 & 89 & 88.1 \\
\hline Lr14b & 86 & 85 & 85 & 91 & 94 & 88 & 82 & 85 & 90 & 87.3 \\
\hline Lr15 & 82 & 79 & 78 & 100 & 100 & 90 & 89 & 100 & 100 & 90.9 \\
\hline Lr16 & 80 & 82 & 83 & 100 & 100 & 89 & 91 & 100 & 100 & 91.7 \\
\hline Lr17 & 79 & 81 & 80 & 100 & 100 & 92 & 89 & 92 & 96 & 89.9 \\
\hline Lr18 & 90 & 92 & 89 & 100 & 100 & 91 & 90 & 97 & 98 & 94.1 \\
\hline Lr19 & 0 & 0 & 0 & 4 & 3 & 2 & 1 & 0 & 0 & 1.1 \\
\hline Lr20 & 100 & 100 & 100 & 100 & 100 & 100 & 100 & 98 & 99 & 99.7 \\
\hline Lr21 & 100 & 100 & 100 & 100 & 100 & 100 & 100 & 92 & 90 & 98.0 \\
\hline Lr22a & 90 & 97 & 95 & 100 & 100 & 100 & 100 & 97 & 99 & 97.6 \\
\hline Lr23 & 85 & 82 & 80 & 90 & 96 & 89 & 89 & 87 & 100 & 88.7 \\
\hline Lr24 & 0 & 0 & 0 & 0 & 0 & 0 & 0 & 0 & 0 & 0.0 \\
\hline Lr25 & 0 & 0 & 0 & 3 & 4 & 2 & 1 & 0 & 0 & 1.1 \\
\hline Lr26 & 51 & 61 & 60 & 72 & 81 & 69 & 71 & 65 & 62 & 65.8 \\
\hline Lr27+Lr31 & 43 & 48 & 37 & 59 & 62 & 59 & 52 & 49 & 47 & 50.7 \\
\hline Lr28 & 0 & 0 & 0 & 0 & 0 & 0 & 0 & 0 & 0 & 0.0 \\
\hline Lr29 & 90 & 93 & 90 & 100 & 100 & 92 & 89 & 100 & 100 & 94.9 \\
\hline Lr30 & 90 & 87 & 79 & 89 & 91 & 90 & 87 & 78 & 82 & 85.9 \\
\hline Lr 32 & 85 & 84 & 83 & 100 & 100 & 89 & 90 & 100 & 100 & 92.3 \\
\hline Lr 33 & 87 & 82 & 85 & 100 & 100 & 90 & 89 & 87 & 97 & 90.8 \\
\hline Lr 34 & 90 & 91 & 92 & 100 & 100 & 88 & 87 & 99 & 100 & 94.1 \\
\hline Lr 35 & 79 & 77 & 75 & 90 & 90 & 90 & 92 & 98 & 100 & 87.9 \\
\hline Lr 36 & 81 & 80 & 90 & 100 & 100 & 89 & 95 & 95 & 98 & 92.0 \\
\hline Lr37 & 84 & 90 & 87 & 100 & 100 & 91 & 89 & 100 & 100 & 93.4 \\
\hline Mean & 71.3 & 72.4 & 71.7 & 80.4 & 81.5 & 76.5 & 75.3 & 76.7 & 78.1 & \\
\hline
\end{tabular}

"cultivars Kharkovskaya 105, Donetskaya 48 and Ukrainka Odeskaya were previously rated highly susceptible to leaf rust in field observations in Ukraine, Varieties Dolgushinskaya and Perlina Lisostepu were rated moderately susceptible. Variety Astet was rated resistant, and varieties Kryzhynka, Prichernomorka, and Smuglyanka were rated highly resistant 
Races of $P$. recondita f. sp. tritici identified in the central part of the forest-steppe region

Seven single-uredinial isolates were obtained from leaves collected from each of 19 Thatcher near-isogenic lines growing in plots in the central part of the foreststeppe region of Ukraine (Table 4). No attempt was made to obtain isolates from the six very resistant lines, and no isolates could be obtained from rusted leaves obtained from the near-isogenic lines with Lr3ka, Lr11, and lr17, because the urediniospores were not viable. Using the standard wheat leaf rust differential varieties of Johnson and Browder (Johnson and Browder 1964), we identified 15 different races among the 133 isolates (Table 4). Three of the races were previously unidentified races found in Ukraine but not included in the international register of wheat leaf rust races (Johnson and Browder 1964). The four most common races were race $6(27.8 \%)$, race $77(18.0 \%)$, race $149(13.5 \%)$, and race X-4 (9.8\%). Six of the 15 races identified were represented by only a single isolate each.

From three to five different leaf rust races were obtained from each of the Thatcher near-isogenic lines (Table 5). As expected, the most common races were found on many of the Thatcher near-isogenic lines. Isolates of races $6,77,149$, and $X 4$ were obtained from $15,14,10$, and 7 different lines, respectively. For each of source near-isogenic line, the frequencies of all the races identified among the seven isolates from that line are presented also in Table 5.
These combined frequencies ranged from $27.1 \%$ for the five races identified from the Lr26 near-isogenic line to $76.6 \%$ for the five races from the Lr14b line. These values can be taken as lower limit estimates of the frequencies of virulence to these lines in the central part of the Ukrainian forest-steppe region in 2007.

Table 4. Frequency of wheat leaf rust races ${ }^{+}$identified in collections ${ }^{\ddagger}$ from near-isogenic Thatcher lines in the central part of Ukrainian forest-steppe region in 2007

\begin{tabular}{|c|c|c|c|}
\hline Race & $\begin{array}{c}\text { Frequency } \\
{[\%]}\end{array}$ & Race & $\begin{array}{c}\text { Frequency } \\
{[\%]}\end{array}$ \\
\hline 6 & 27.8 & 161 & 0.8 \\
\hline 61 & 6.8 & 163 & 0.8 \\
\hline 62 & 0.8 & 172 & 0.8 \\
\hline 77 & 18.0 & 192 & 6.0 \\
\hline 92 & 4.5 & $\mathrm{X}-4^{\S}$ & 9.8 \\
\hline 123 & 6.0 & $\mathrm{X}-37^{\S}$ & 0.8 \\
\hline 144 & 3.0 & $\mathrm{X}-68^{\S}$ & 0.8 \\
\hline 149 & 13.5 & & \\
\hline
\end{tabular}

${ }^{+}$races were identified using the 8 standard wheat leaf rust differential varieties (Johnson and Browder 1964)

$\ddagger$ A total of 133 single-uredinial isolates were tested

$\S \mathrm{X}$ races indicate previously unidentified races found in Ukraine that are not included in the international register of wheat leaf rust races (Johnson and Browder 1964)

Table 5. Wheat leaf rust races obtained from naturally infected near-isogenic Thatcher ${ }^{\dagger}$ lines in the central part of Ukrainian forest-steppe region in 2007

\begin{tabular}{|c|c|c|c|c|c|}
\hline Line & Races obtained & $\begin{array}{c}\text { Combined freq. } \\
{[\%]^{\ddagger}}\end{array}$ & Line & Races obtained & $\begin{array}{c}\text { Combined freq. } \\
{[\%]^{\ddagger}}\end{array}$ \\
\hline Thatcher & $6,77,149$, X-4 & 69.1 & Lr14b & $6,77,92,144,149$, X-4 & 76.6 \\
\hline Lr1 & $77,144,149,172$ & 35.3 & Lr15 & $6,61,149$ & 48.5 \\
\hline Lr2a & $77,123,192$ & 30.0 & Lr16 & $6,77,92,192$ & 56.3 \\
\hline Lr2b & $6,77,149,192$, X-4, X-37 & 75.9 & Lr20 & $6,77,123,149$ & 65.3 \\
\hline Lr2c & $6,77,144,149$ & 62.3 & Lr26 & $92,123,161,192, X-4$ & 27.1 \\
\hline Lr3 & $6,61,77,92,149$ & 64.6 & Lr30 & $6,77,149,163$, X-4 & 68.9 \\
\hline Lr10 & $6,61,77,92$ & 57.1 & Lr33 & 6,61, X-4 & 44.4 \\
\hline Lr12 & 6,77, X-4 & 55.6 & Lr34 & $6,77,192$, X-68 & 52.6 \\
\hline Lr13 & 6,62, X-4 & 38.4 & Lr37 & $77,92,123,149,192$ & 48.0 \\
\hline Lr14a & $6,61,149$ & 48.4 & - & - & \\
\hline
\end{tabular}

${ }^{\dagger}$ seven isolates from each line were tested on the eight standard wheat leaf rust differential varieties (Johnson and Browder 1964)

$\ddagger$ sum of the frequencies of the races found on indicated near-isogenic lines

\section{DISCUSSION}

Winter wheat varieties selected for leaf rust resistance have been grown in the eastern part of Ukrainian foreststeppe over quite a long period of time. This is a situation that may be expected to result in an accumulation of virulence alleles in the local population of $P$. recondita f. sp. tritici. Most of the Thatcher near-isogenic wheat lines appeared susceptible in a natural leaf rust epiphytotic in the eastern part of the forest-steppe region in 2007. However, the near-isogenic lines with Lr9, Lr19, Lr24, Lr25, and Lr28 showed little or no leaf rust infection in the field plots in 2004, indicating that virulence to these resistance genes is lacking in the population of $P$. recondita $\mathrm{f}$. sp. trit$i c i$ at that location. In addition, seedlings of near-isogenic lines with Lr9, Lr19, Lr24, Lr25, and Lr28 developed little or no leaf rust when inoculated with bulk collections of the fungus urediniospores from nine different Ukrainian varieties of winter wheat in the eastern part of the foreststeppe region. These results are consistent with the virulence surveys of 2002 and 2003 in the eastern part of the 
forest-steppe region (Elyasi-Gomari and Panteleev 2006). Virulence to Lr9, Lr24, Lr25 and Lr28 was not found among races of $P$. recondita $\mathrm{f}$. $\mathrm{sp}$. tritici collected in Ukraine in 2002 and 2003. Virulence to Lr19 was infrequent in 2003 and 2004, being found mainly among isolates of previously unidentified races of leaf rust (Elyasi-Gomari and Panteleev 2005, 2006).

Near-isogenic lines with Lr27+31, Lr35, and Lr36 appeared resistant with leaf rust infection of $10 \%$ or less in a natural leaf rust epiphytotic in the eastern part of the forest-steppe region in 2007. The near-isogenic line with Lr26 appeared moderately susceptible. The lines with Lr26 and Lr27+31 also developed less severe leaf rust infection than the fully susceptible lines when inoculated with spores collected from Ukrainian winter wheat varieties in the eastern part of the forest-steppe region, which suggests that virulence to Lr26 and Lr27+31 is still relatively low there.

In the central part of Ukrainian forest-steppe diversity of cultivated wheat varieties is much wider than in the eastern part. A higer diversity of resistance genotypes is beneficial, because it does not impose as much selection pressure for the accumulation of specific virulence genes in the pathogen population. Many of the near-isogenic Thatcher lines exposed to the natural epiphytotic in field plots in the central part of the forest-steppe region developed less leaf rust than those exposed to the leaf rust population in the eastern part of the forest-steppe region in 2007. For example, lines with Lr9, Lr19, Lr23, Lr24, Lr25, Lr28, Lr29, and Lr37 were rated very resistant, and lines with Lr18, Lr21, Lr22a, Lr27+31, and Lr36 were rated resistant in 2007 in the central part of the forest-steppe region. Virulence to these resistance genes previously was reported lacking in the Ukrainian leaf rust population (Lesovaya 2004).

Resistance gene Lr26 was effective and widely used in the former USSR starting in the 1970s. Lr26 lost much of its effectiveness in the 1990s, particularly in Ukraine (Lesovoj 1997). The decline in effectiveness of Lr26 can be attributed to the increased use of wheat varieties with the $1 B / 1 R$ translocation from rye, which carries Lr26 in addition to the genes Sr31 for stem rust resistance, Yr9 for yellow rust resistance and $P m 8$ for powdery mildew resistance. In the current study, the near-isogenic line with Lr26 developed moderate levels of infection compared to most of the near-isogenic lines in the eastern part of the forest-steppe region. In the central part of the foreststeppe region the Lr26 near-isogenic line showed less infection and was rated moderately resistant or resistant. The three most common leaf rust races isolated from near-isogenic Thatcher lines in 2007 from field plots in the central part of the forest-steppe region (races 6, 77 and 149) occurred among isolates from 15,14 , and 10 different near-isogenic lines, respectively, but races 6,77 , and 149 did not occur among the isolates from the Lr26 line. This suggests that the leaf rust races favoured by selection in recent years in the central part of the forest-steppe region may lack virulence to Lr26. These results indicate that Lr26 regained some of its effectiveness in Ukraine in recent years, although it is not as effectiveness that had been in the 1970s.
It was noted that the greatest effectiveness of resistance to leaf rust in wheat can be attributed to resistance genes derived from wild relatives of wheat rather than from genes originating from Triticum aestivum (Goel and Saini 2001; Menon and Formar 2001; Vlasenko et al. 2000). For example, Lr9 was transferred to wheat from T. umbellulatum, Lr19, Lr24 and Lr29 were from Agropyron elongatum, Lr21, Lr22 and Lr32 genes were from T. tauschi, and Lr28, Lr35 and Lr36 were from T. speltoides. Our results confirm that most of these genes still provide highly effective resistance against leaf rust in Ukraine. On the other hand, genes such as Lr2c, Lr3, Lr3ka, Lr10, Lr16, Lr30 and Lr37 have been no longer effective in Ukraine and should be withdrawn from breeding programs or supplemented with more effective resistance genes. This is also true for Lr23, which formerly provided valuable resistance in Ukraine (Kolmer 2002), but now is ineffective in the eastern part of the forest-steppe region although it remained effective in 2007 in the central part.

In 2007 most common races in the central part of the forest-steppe region were races 6, 77, 149, and X-4. Race $X-4$ is a new race that was first discovered by the scientists of the Institute for Plant Protection (Kiev, Ukraine) on the territory of Ukraine. Up to the late 1990s 19 new races were identified in Ukraine that were not listed in the International Catalogue for leaf rust races. Between 1996 and 2004 the list of such races reached 68 (Lesovaya 2004; Lesovoj and Panteleev 2000). No new races were added to the list in 2007. Some of the races not listed in the International Catalogue may be referred to as "one-day" races that were identified only once and did not remain at detectable levels in the $P$. recondita $\mathrm{f}$. sp. tritici population. A small number of the new races, however, was found repeatedly in the population over the period of some years. Among these are X-37 race (first discovered in 1997) and $X-68$ (first discovered in 2003). Both race $X-37$ and race $\mathrm{X}-68$ were identified as single isolates collected in 2007.

The level of virulence complexity in the pathogen population can be represented by the ratio of highly virulent races: moderately virulent races: relatively avirulent races. According to Voronkova (1980), the number of virulent races in the leaf rust population was almost three times lower than the number of avirulent and moderately virulent races. This ratio was observed in 2002 with highly virulent: moderately virulent: avirulent races occurring at a ratio of $18: 18: 10$ and in 2003 with a ratio of $14: 12: 10$. In 2007 the ratio of races was almost $1: 1$ instead of $1: 3$. This might reflect a small number of races found in 2007, 15, compared to 36 and 46 races found in 2002 and 2003 in Ukraine. It appears that the numbers of virulent races isolated in recent surveys in Ukraine have not declined as much as the number of moderately virulent and avirulent races identified in the surveys. The changes in the $P$. recondita f. sp. tritici population could have been caused by changes in the resistant genotypes of the most commonly grown wheat cultivars or as a consequence of some environmental changes (in particular, 2002-2003 winter) that might have changed the survival of virulent and avirulent races in ways that were not fully understood. The racial composition and virulence of $P$. recondita $\mathrm{f}$. sp. tritici populations has influenced most by temperature and relative 
humidity (Alekseeva et al. 1990). Lower than normal summer temperatures and high relative humidity increased the survival of virulent races relative to survival of avirulent races. In the summer of 2007 humidity was high and temperatures were under $15-20^{\circ} \mathrm{C}$. Precipitation was greater than normal at the time of wheat flowering and temperatures dropped, especially at night. These conditions benefited survival of the virulent races. The majority of wheat varieties grown in the central part of Ukrainian forest-steppe have resistance genes that are ineffective against the most common races 6, 77, 149, and X-4.

There were some notable differences between the frequencies of leaf rust races identified in the central part of the forest-steppe region in 2007 and the frequencies of races found in the eastern part in 2002 and 2003 (ElyasiGomari and Panteleev 2006). The two most common races in the eastern part were race 61 at $24.8 \%$ in 2002 and $24.0 \%$ in 2003 and race 149 at $23.8 \%$ in 2002 and $22.0 \%$ in 2003 . Both of these races were found at considerably lower frequencies in the central part in 2007; race 61 occurred at $6.8 \%$ and race 149 occurred at $13.5 \%$. Race 184 was relatively common in the eastern part of the forest-steppe region at $15.6 \%$ in 2002 and $11.5 \%$ in 2003 , but race 184 was not found in the central part in 2007. On the other hand, races 6 and 77 were more common in the central part in 2007 than in the eastern part in 2002 and 2003. Race 6 occurred at $27.8 \%$ in 2007 but at only $0.2 \%$ and $1.2 \%$ in the eastern part of the forest-steppe region in 2002 and 2003. Race 77, which is virulent on all 8 of the standard differentials of Johnson and Browder (Johnson and Browder 1964), occurred at $18.0 \%$ in the central part in 2007 but occurred at $10.6 \%$ in 2002 and $7.8 \%$ in 2003 in the eastern part of the forest-steppe region. Also, race 57 occurred at $5.7 \%$ in 2002 and $12.9 \%$ in 2003 in the east part but was not found in the central part of the forest-stepper region in 2007. Thus, the composition of the leaf rust populations appears to differ between the eastern and central parts of the forest-steppe region of Ukraine in addition to changing from year to 3 years in response to the use of resistant wheat varieties in the two areas. This shows that continued regional surveys of virulence in $P$. recondita $\mathrm{f}$. $\mathrm{sp}$. trit$i c i$ are necessary to support programs of breeding wheat cultivars with effective leaf rust resistance in Ukraine.

\section{ACKNOWLEDGEMENTS}

We thank Prof. Dr. Kurt J. Leonard (from Department of Plant Pathology, University of Minnesota) and Prof. Dr. Lesovoj M. Pavlovich (from Institute of Plant Protection, Kiev-Ukraine) for comments on the manuscript and for the technical review of the manuscript.

\section{REFERENCES}

Alekseeva T.P., Smirnova A.A., Terekhov V.I. 1990. Prognoz sostava populiatsi vozbuditelia buroi pzhavchini pshenitsi. Zakhist Roslin, Kiev. 9, p. 18. [In Russian].

Anikster Y., Bushnell W.R., Eilam T., Manisterski J., Roelfs A.P. 1997. Puccinia recondita causing leaf rust on cultivated wheats, wild wheats, and rye. Can. J. Bot. 75: 2082-2096.
Bartos P., Hanzalova A., Stuchlikova E. 2001a. Wheat leaf rust races/pathotypes in Czech Republic in 1999-2000. Plant Protec. Sci. 1:10-16.

Bartos P., Huszar J., Hansalova A., Hersova E. 2001b. Wheat leaf rust races/pathotypes in Slovakia in 1999-2000. Plant Protec. Sci. 3: 85-90.

Elyasi-Gomari S., Panteleev V.K. 2006. Virulence polymorphism of Puccinia recondita f. sp. tritici and effectiveness of Lr-genes for leaf rust resistance of wheat in Ukraine. Plant Dis. 90: 853-857.

Elyasi-Gomari S., Panteleev V.K. 2005. The resistance of current varieties in spring wheat to leaf rust (Puccinia recondita tritici) in the eastern parts of forest-steppe in Ukraine. The state Nikitsky Bot. Garden 91: 121-138.

Goel R.K., Saini R.G. 2001. Effectiveness of Triticum tauschii (Aegilops squarossa) derived Lr genes in conferring resistance to Indian races of leaf rusn (Puccinia recondita tritici) of wheat. Wheat Inf. Ser. 93: 19-21.

Johnston C.O., Browder L.E. 1964. Seventh revision of the international register of physiologic races of Puccinia recondita f. sp. tritici. Plant Dis. Rep. 50: 756-760.

Kolmer J.A. 2002. Virulence phenotypes of Puccinia triticina in the South Atlantic States in 1999. Plant Dis. 3: 288-291.

Kolmer J.A. 1997. Virulence phenotypes of Puccinia recondita f. sp. tritici isolates from Canada to genes for adult-plant resistance to wheat leaf rust. Plant Dis. 3: 267-271 [In Ukrainian].

Lesovaya G.M. 2004. Race composition of the population of the wheat leaf rust. Zakhist i Karantin Roslin. Kiev. 50: 133-140.

Lesovoj M.P. 1997. Theoretical and methodological fundamentals of genetic protection of varieties and hybrids against harmful organisms. p. 47-55. In: Informatsionni biolleten VPRS MOBB. Maтeriali VII cecci Generalhoi Accamblei. 12-16 мауа 1997. [In Russian].

Lesovoj M.P., Panteleev V.K. 2000. Scientific-Methodic Basics of Creation of Gene Bank in Wheat Resistance to Brown Leaf Rust. Metodichni Rekomendatsii Kharkov: publisher, 35 pp. [In Ukrainian].

Long D.L., Leonard K.J., Hughes M.E. 2002. Virulence in Puccinia triticina on wheat in the United States in 1999. Plant Dis. 86: 15-19.

Mains E.B., Jackson H.S. 1926. Physiologic specialization in the leaf rust of wheat Puccinia triticina Erikss. Phytopathology 16: 89-120.

Menon M.K., Formar S.M. 2001. Transfer of Agropyron elongatum - derived rust resistance genes Sr24 and Lr24 into some Indian bread wheat cultivars. Wheat Inf. Ser. 93: 20-24.

Peterson R.F., Campbell A.B., Hannah A.E. 1948. A diagrammatic scale for estimating rust intensity of leaves and stems of cereals. Can. J. Res. Sect. 26: 496-500.

Singh R.P.1991. Pathogenicity variations of Puccinia recondita f. sp. tritici and P. graminis f. sp. tritici in wheat-growing areas of Mexico during 1988 and 1989. Plant Dis. 75: 790-794.

Shopina V.V. 1967. Definition of Races of Brown, Stem, and Yellow Rusts of Wheat. This is the old methodology, which found in the library of Plant Protection Institute of Kyiv and Kharkov National Agrarian University, Leningrad, 48 pp. [In Russian].

Starakhov T.D. 1951. Otsenka Sortov Pshenytsi po Immunosti i Porazhayemosti Boroj Listovoj Rzhavchynoj P. recondita 
Rob. et Desm. f. sp. tritici Erikss. (Methodology - Appendix). Kharkov, Publisher, 11 pp. [In Russian].

Vlasenko V.A., Koliochi V.T., Borsuk G.Yu. 2000. Selektsiono-Genetichna Khrakteristika Mironivskikh Sortiv Ozimoi Miakoi Pshenitsi. Visnik Agrarnoj Nauki, Kiev.12: 27-28. [In Russian].

Voronkova A.A. 1980. Genetika-Immunologicheskie Osnovi Selektsi Pshenitsi na Ustoichivosti k Pzhavchini. Moskva, 192 pp. [In Russian].

\section{POLISH SUMMARY}

\section{WIRULENCJA PUCCINIA RECONDITA F. SP. TRITICI W STOSUNKU DO PSZENICY OZIMEJ NA UKRAINIE W 2007 ROKU}

Thatcher i 36 blisko-izogenicznych linii Thatcher z genami Lr warunkującymi odporność na Puccinia recondita f. sp. tritici wysadzano indywidualnie do wazonów na poletkach doświadczalnych w każdej z lokalizacji we wschodniej i centralnej części w rejonie las-step na Ukra- inie, gdzie były eksponowane na naturalną epifitozę rdzy. Nasilenie choroby na liniach wskazywało, że Lr9, Lr19, Lr24, Lr25 i Lr28 warunkowały wysoce efektywną odporność w obydwóch lokalizacjach. Linie z genami Lr27 + Lr31, Lr35 i Lr36 były odporne we wschodniej lokalizacji i wysoce odporne w centralnej lokalizacji. Całościowe kolekcje $P$. recondita $\mathrm{z}$ pól $\mathrm{z}$ dziewięcioma ukraińskimi odmianami pszenicy we wschodniej lokalizacji użyto do inokulacji siewek 36. blisko-izogenicznych linii Thatcher. Na liniach z Lr9, Lr19, Lr24, Lr25 i Lr28 nie było, lub prawie nie było uredinów. Ogółem 133 jednozarodnikowych izolatów uzyskanych z 19 wrażliwych, blisko-izogenicznych linii Thatcher na polowych poletkach w centralnej części regionu las-step określono do rasy, przy zastosowaniu ośmiu standardowych linii różnicujących Johnsona i Brondera. Najpospolitszymi rasami były: $6(27,8 \%)$, 77 (18,0\%), 149 (13,5\%) i X-4 (9,8\%). Najpospolitszych ras nie znaleziono na linii z Lr26 i może ona nie wykazywać wirulencji w stosunku do tej linii. 